\title{
Mechanism of selective catalytic oxidation of ammonia to nitrogen over $\mathrm{Ag} / \mathrm{Al}_{2} \mathrm{O}_{3}$
}

\author{
Li Zhang, Hong He* \\ State Key Laboratory of Environmental Chemistry and Ecotoxicology, Research Center for Eco-Environmental Sciences, Chinese Academy of Sciences, Beijing 100085, PR China
}

\section{A R T I C L E I N F O}

\section{Article history:}

Received 7 January 2009

Revised 12 August 2009

Accepted 27 August 2009

Available online 1 October 2009

\section{Keywords:}

Selective catalytic oxidation

$\mathrm{NH}_{3}$

$\mathrm{Ag} / \mathrm{Al}_{2} \mathrm{O}_{3}$

Mechanism

$\mathrm{O}_{2}$ uptake

In situ DRIFTS

\begin{abstract}
A B S T R A C T
The mechanism of selective catalytic oxidation ( $\mathrm{SCO}$ ) of $\mathrm{NH}_{3}$ over $\mathrm{Ag} / \mathrm{Al}_{2} \mathrm{O}_{3}$ was studied by $\mathrm{NH}_{3}$ temperature-programed oxidation, $\mathrm{O}_{2}$-pulse adsorption, and in situ DRIFTS of $\mathrm{NH}_{3}$ adsorption and oxidation. The essence which affects the low temperature activity of $\mathrm{Ag} / \mathrm{Al}_{2} \mathrm{O}_{3}$ has been elucidated through the mechanism study. Different $\mathrm{Ag}$ species on $\mathrm{Ag} / \mathrm{Al}_{2} \mathrm{O}_{3}$ significantly influence $\mathrm{O}_{2}$ uptake by catalysts; while different oxygen species affect the activity of $\mathrm{NH}_{3}$ oxidation at low temperature. The activated $-\mathrm{NH}$ could react with the atomic oxygen $(\mathrm{O})$ at low temperatures $\left(<140^{\circ} \mathrm{C}\right)$; however, the $-\mathrm{NH}$ could also interact with the $\mathrm{O}_{2}$ at temperatures above $140^{\circ} \mathrm{C}$. At low temperatures $\left(<140^{\circ} \mathrm{C}\right), \mathrm{NH}_{3}$ oxidation follows the $-\mathrm{NH}$ mechanism. However, at temperatures above $140^{\circ} \mathrm{C}, \mathrm{NH}_{3}$ oxidation follows an in situ selective catalytic reduction (iSCR) mechanism (two-step formation of $\mathrm{N}_{2}$ via the reduction of an in situ-produced $\mathrm{NO}_{x}$ species by a $\mathrm{NH}_{x}$ species).
\end{abstract}

(c) 2009 Elsevier Inc. All rights reserved.

\section{Introduction}

Selective catalytic oxidation ( $\mathrm{SCO}$ ) of ammonia $\left(\mathrm{NH}_{3}\right)$ with $\mathrm{O}_{2}$ to nitrogen gas $\left(\mathrm{N}_{2}\right)$ and $\mathrm{H}_{2} \mathrm{O}$ at low temperatures is an efficient method to abate $\mathrm{NH}_{3}$ pollution. This SCO reaction has two important parameters: the selectivity and the application temperature. To rationally develop a process for $\mathrm{NH}_{3}$ oxidation to $\mathrm{N}_{2}$ over catalysts, the reaction mechanism must be clarified.

While several studies have examined the SCO process, the mechanism of $\mathrm{NH}_{3}$ oxidation and $\mathrm{N}_{2}$ formation is still uncertain. Three major reaction pathways have been proposed for the SCO of $\mathrm{NH}_{3}$ to $\mathrm{N}_{2}$ over different catalysts [1-13]. Zawadzki [1] proposed an imide (NH) mechanism in which the first step yields $\mathrm{NH}$, and then the $\mathrm{NH}$ reacts with atomic oxygen $(\mathrm{O})$ to form nitroxyl (HNO) and further conversion to $\mathrm{N}_{2}$ or nitrous oxide $\left(\mathrm{N}_{2} \mathrm{O}\right)$, or $\mathrm{NH}$ could even react with molecular $\mathrm{O}_{2}$ to produce nitric oxide (NO). This mechanism was mainly supported by the results obtained on Pt or transition metal oxide catalysts [1-5]. Two other insights into the reaction mechanism of $\mathrm{NH}_{3}$ oxidation have been proposed in recent years [6-13]. One is the SCO by a direct route involving a hydrazinium-type intermediate $[7,8]$. This mechanism has been reported mainly on the transition metal oxide catalysts such as $\mathrm{CuO} / \mathrm{Al}_{2} \mathrm{O}_{3}, \mathrm{Fe}_{2} \mathrm{O}_{3} / \mathrm{TiO}_{2}, \mathrm{CrO}_{x} / \mathrm{TiO}_{2}, \mathrm{CoO}_{x} / \mathrm{TiO}_{2}$, and $\mathrm{CuO} /$ $\mathrm{TiO}_{2}$ [7,8]. The other is a two-step mechanism called in situ or "internal" selective catalytic reduction (iSCR), which involves the oxidation of a significant percentage of $\mathrm{NH}_{3}$ into $\mathrm{NO}_{x}$ species, and

\footnotetext{
* Corresponding author. Fax: +8610 62923563.

E-mail address: honghe@rcees.ac.cn (H. He).
}

the $\mathrm{NO}_{x}$ species subsequently react with $\mathrm{NH}_{3}$ to form $\mathrm{N}_{2}$ [9-11]. Many noble metal catalysts, such as $\mathrm{Ag}$ (powder), $\mathrm{Pt}, \mathrm{Pt} / \mathrm{Al}_{2} \mathrm{O}_{3}$, $\mathrm{Rh} / \mathrm{Al}_{2} \mathrm{O}_{3}, \mathrm{Pd} / \mathrm{Al}_{2} \mathrm{O}_{3}, \mathrm{Pt}-\mathrm{ZSM}-5, \mathrm{Pd}-\mathrm{ZSM}-5$, and Rh-ZSM-5, have been suggested to follow this iSCR route [9-11].

Different reaction mechanisms of $\mathrm{NH}_{3}$ oxidation are reportedly associated with different oxygen species [1,7,14-16]. Zawadzki [1] proposed that $\mathrm{O}$ was necessary for the very rapid formation of $\mathrm{NH}$, as well as for the HNO intermediate and $\mathrm{N}_{2} \mathrm{O}$ production. The hydrazinium-type intermediate mechanism had been suggested under conditions of little or limited $\mathrm{O}_{2}$ availability; the only oxygen available was that associated with the metal oxide catalysts, and the catalyst testing was carried out in an essentially reducing environment. At higher $\mathrm{O}_{2}$ concentrations, $\mathrm{NH}_{3}$ mainly interacts with molecular $\mathrm{O}_{2}$ and follows the iSCR mechanism [7,14].

Recently, Gang et al. [11,13] reported that alumina-supported $\mathrm{Ag}\left(\mathrm{Ag} / \mathrm{Al}_{2} \mathrm{O}_{3}\right)$ catalysts were extremely active in $\mathrm{NH}_{3}$ oxidation at low temperatures, and the performance of the $\mathrm{Ag} / \mathrm{Al}_{2} \mathrm{O}_{3}$ catalyst was even superior to that of noble metal catalysts. We investigated the role of $\mathrm{Ag}$ species on $\mathrm{Ag} / \mathrm{Al}_{2} \mathrm{O}_{3}$ in the activity and selectivity of $\mathrm{NH}_{3}$ oxidation [17]. The state of the Ag species and Ag particle size was found to significantly influence the activity and selectivity of $\mathrm{NH}_{3}$ oxidation over $\mathrm{Ag} / \mathrm{Al}_{2} \mathrm{O}_{3}$. $\mathrm{Ag}^{0}$ was proposed to be the main active species of $\mathrm{NH}_{3}$ oxidation at low temperatures $\left(<140^{\circ} \mathrm{C}\right)$, whereas $\mathrm{Ag}^{+}$was also active at higher temperatures $\left(>140{ }^{\circ} \mathrm{C}\right)$.

Gang et al. [11,13] revealed that the $\mathrm{NH}_{3}$ oxidation over the $\mathrm{Ag}$ based catalysts followed the iSCR mechanism. They reported that the $\mathrm{NH}_{3}$ oxidation activity at low temperatures was related to the catalyst's ability to promote dissociative or non-dissociative adsorption of $\mathrm{O}_{2}$ [11]. However, the roles of different oxygen 
species in the activity and the reaction mechanism over the $\mathrm{Ag} /$ $\mathrm{Al}_{2} \mathrm{O}_{3}$ have not been studied in detail. The role of different oxygen species in the activity and reaction mechanism of $\mathrm{NH}_{3}$ oxidation over $\mathrm{Ag} / \mathrm{Al}_{2} \mathrm{O}_{3}$ needs to be determined. Since the active species on $\mathrm{Ag} / \mathrm{Al}_{2} \mathrm{O}_{3}$ for $\mathrm{NH}_{3}$ oxidation are different in different temperature regions [17], investigating the role of different $\mathrm{Ag}$ species in the reaction process is important. Such information may be useful in the development of an improved process of $\mathrm{NH}_{3}$ oxidation over $\mathrm{Ag} / \mathrm{Al}_{2} \mathrm{O}_{3}$.

In this study, the role of different oxygen species in the activity and reaction mechanism of $\mathrm{SCO}$ of $\mathrm{NH}_{3}$ over $\mathrm{Ag} / \mathrm{Al}_{2} \mathrm{O}_{3}$ was studied in detail. $\mathrm{O}_{2}$-pulse adsorption was used to measure the $\mathrm{O}_{2}$ uptake on $\mathrm{Ag} / \mathrm{Al}_{2} \mathrm{O}_{3}$. Temperature-programed oxidation (TPO) and diffuse reflectance infrared Fourier transform spectroscopy (DRIFTS) were used to clarify the possible reaction mechanisms.

In this article, we have elucidated the essence which affects the low temperature activity of $\mathrm{Ag} / \mathrm{Al}_{2} \mathrm{O}_{3}$ through the mechanism study. Different $\mathrm{Ag}$ species significantly influence $\mathrm{O}_{2}$ uptake by catalysts, and different oxygen species affect low temperature activity and reaction routes. Adsorbed $\mathrm{NH}_{3}$ mainly interacts with chemisorbed oxygen atom on $\mathrm{Ag} / \mathrm{Al}_{2} \mathrm{O}_{3}$ at low temperatures $\left(<140{ }^{\circ} \mathrm{C}\right)$. In contrast, at temperatures above $140^{\circ} \mathrm{C}$, adsorbed $\mathrm{NH}_{3}$ can also react with gas phase $\mathrm{O}_{2}$ to produce $\mathrm{N}_{2}$. Accordingly, the reaction route of $\mathrm{NH}_{3}$ oxidation over $\mathrm{Ag} / \mathrm{Al}_{2} \mathrm{O}_{3}$ is different in different temperature regions. At low temperatures $\left(<140^{\circ} \mathrm{C}\right), \mathrm{NH}_{3}$ oxidation follows the $-\mathrm{NH}$ mechanism, while at temperatures above $140^{\circ} \mathrm{C}$, it follows the iSCR mechanism.

\section{Materials and methods}

\subsection{Catalyst preparation}

The catalyst used in this study was $10 \mathrm{wt} . \% \mathrm{Ag} / \mathrm{Al}_{2} \mathrm{O}_{3}$ prepared by an impregnation method using $\gamma-\mathrm{Al}_{2} \mathrm{O}_{3}$ powder $\left(250 \mathrm{~m}^{2} \mathrm{~g}^{-1}\right)$ and an appropriate amount of $\mathrm{AgNO}_{3}\left(7.874 \mathrm{mg} \mathrm{cm}^{-3}\right)$ aqueous solution. After impregnation, the excess water was removed in a rotary evaporator at $80^{\circ} \mathrm{C}$. The sample was first dried at $120^{\circ} \mathrm{C}$ overnight followed by calcination at $600{ }^{\circ} \mathrm{C}$ in air for $3 \mathrm{~h}$. The weight ratio of $\mathrm{Ag}$ is measured with respect to the support $\gamma-\mathrm{Al}_{2} \mathrm{O}_{3}$.

\section{2. $\mathrm{NH}_{3}$ temperature-programed oxidation $\left(\mathrm{NH}_{3}-\mathrm{TPO}\right)$}

$\mathrm{NH}_{3}$ temperature-programed oxidation $\left(\mathrm{NH}_{3}-\mathrm{TPO}\right)$ experiments were carried out over fresh and $\mathrm{H}_{2}$-pretreated $\mathrm{Ag} / \mathrm{Al}_{2} \mathrm{O}_{3}$ catalysts using a fixed-bed continuous flow micro-reactor system equipped with a computer-interfaced quadruple mass spectrometer (Hiden WR13012 UK). Typically, $100 \mathrm{mg}$ of sample was pretreated by heating in a flowing stream $\left(40 \mathrm{~cm}^{3} \mathrm{~min}^{-1}\right)$ of $\mathrm{O}_{2} / \mathrm{He}(10 \mathrm{vol} . \%)$ from room temperature to $500^{\circ} \mathrm{C}\left(25^{\circ} \mathrm{C} \mathrm{min}{ }^{-1}\right)$. This was done to remove the water and desorb unwanted impurities. The temperature was held at $500{ }^{\circ} \mathrm{C}$ for $0.5 \mathrm{~h}$ and then cooled to room temperature under flowing gas $\left(\mathrm{O}_{2} / \mathrm{He}\right)$. Prior to the $\mathrm{NH}_{3}$ oxidation, the catalyst was reduced in situ by heating from room temperature to $400{ }^{\circ} \mathrm{C}\left(10^{\circ} \mathrm{C} \mathrm{min}^{-1}\right)$ in a $\mathrm{H}_{2} / \mathrm{Ar}(5 \mathrm{vol} . \%)$ flow $\left(40 \mathrm{~cm}^{3} \mathrm{~min}^{-1}\right)$. Subsequently, the sample was kept at this temperature for $2 \mathrm{~h}$; the temperature was then lowered to $50{ }^{\circ} \mathrm{C}$, followed by a He flushing period for $1 \mathrm{~h}$. At $50{ }^{\circ} \mathrm{C}$, the He flow was switched to a flow of $\mathrm{NH}_{3} 500$ ppm, $\mathrm{O}_{2} 10$ vol.\%, He as carrier for $2 \mathrm{~h}$, and the total flow rate was $100 \mathrm{~cm}^{3} \mathrm{~min}^{-1}$. Then the sample temperature was increased from $50{ }^{\circ} \mathrm{C}$ to $500{ }^{\circ} \mathrm{C}$ at a rate of $10^{\circ} \mathrm{C} \mathrm{min}^{-1}$ and the TPO data were recorded with mass spectrometer. A similar experiment, without the $\mathrm{H}_{2}$ pretreatment prior to the $\mathrm{NH}_{3}$-TPO, was also performed over fresh $\mathrm{Ag} / \mathrm{Al}_{2} \mathrm{O}_{3}$.

\section{3. $\mathrm{O}_{2}$-pulse adsorption}

$\mathrm{O}_{2}$ uptake was determined by $\mathrm{O}_{2}$-pulse adsorption at various temperatures over the fresh and $\mathrm{H}_{2}$-pretreated $\mathrm{Ag} / \mathrm{Al}_{2} \mathrm{O}_{3}$ catalysts using a Quantasorb-18 automatic instrument (Quanta Chrome Instrument $\mathrm{Co}$.). Prior to the $\mathrm{O}_{2}$-pulse adsorption, $300 \mathrm{mg}$ of sample was pretreated in situ with a flow of 5 vol.\% $\mathrm{H}_{2} / \mathrm{Ar}$

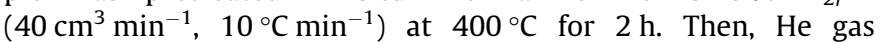
$\left(40 \mathrm{~cm}^{3} \mathrm{~min}^{-1}\right)$ was passed over the sample for $1.5 \mathrm{~h}$. After cooling to the desired temperature in $\mathrm{He}, \mathrm{O}_{2}$ pulses $(4.46 \mu \mathrm{mol})$ were then injected in a He carrier over the sample, with a time interval between $\mathrm{O}_{2}$ pulses of almost $100 \mathrm{~s}$. The $\mathrm{O}_{2}$ signal was analyzed online with an Autosorb-1-C TCD controller. A similar $\mathrm{O}_{2}$-pulse adsorption experiment was performed over the fresh $\mathrm{Ag} / \mathrm{Al}_{2} \mathrm{O}_{3}$, without the $\mathrm{H}_{2}$ pretreatment prior to the $\mathrm{O}_{2}$-pulse adsorption.

\subsection{Fourier transform infrared (FTIR) spectroscopy studies}

In situ DRIFTS spectra were recorded in a NEXUS 670-FTIR equipped with a smart collector and a liquid $\mathrm{N}_{2}$-cooled MCT detector. The sample (about $30 \mathrm{mg}$ ) for study was finely ground and placed in a ceramic crucible. A feed gas mixture, controlled by mass flow meters, was supplied at a flow rate of $100 \mathrm{~cm}^{3} \mathrm{~min}^{-1}$. The wafers were first treated at $500{ }^{\circ} \mathrm{C}$ in a flow of high purity 10 vol.\% $\mathrm{O}_{2} /$ $\mathrm{N}_{2}$ for $0.5 \mathrm{~h}$ and then cooled to room temperature. At each temperature, the background spectrum was recorded in flowing $\mathrm{N}_{2}$ and was subtracted from the sample spectrum obtained at the same temperature. All spectra were recorded at a resolution of $4 \mathrm{~cm}^{-1}$ with 100 accumulated scans.

The isotope experiment was performed in an IR cell, which was connected to a vacuum system, and it could be kept below $10^{-4}$ Torr by the pump. In this paper, the spectra are displayed in absorbance.

\section{Results}

\section{1. $\mathrm{NH}_{3}-\mathrm{TPO}$}

$\mathrm{NH}_{3}$-TPO experiments were performed separately on the fresh and $\mathrm{H}_{2}$-pretreated $10 \mathrm{wt} . \% \mathrm{Ag} / \mathrm{Al}_{2} \mathrm{O}_{3}$ catalysts to investigate the $\mathrm{NH}_{3}$ oxidation activity over the two catalysts and the variety of products produced in different temperature regions (Fig. 1). $\mathrm{NH}_{3}$

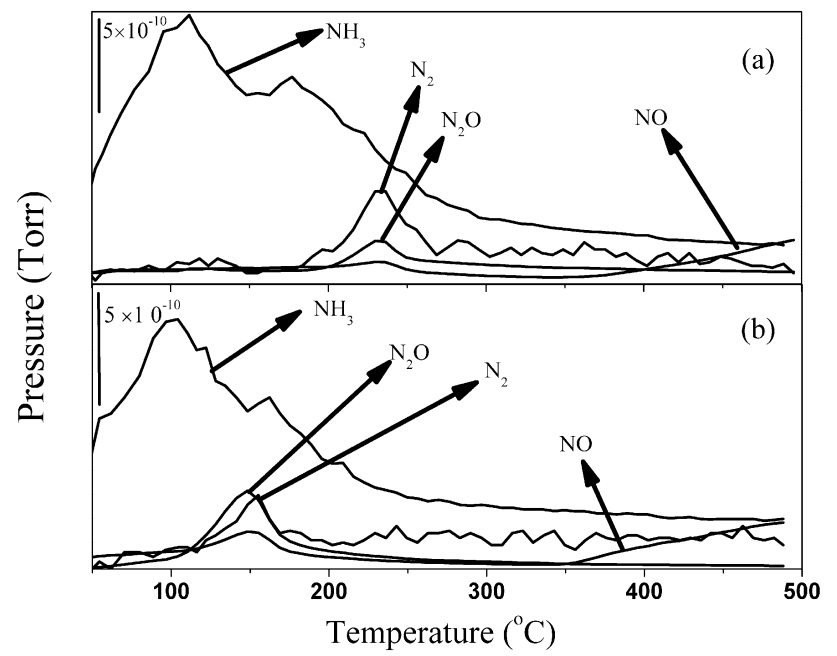

Fig. 1. $\mathrm{NH}_{3}$ temperature-programed oxidation $\left(\mathrm{NH}_{3}-\mathrm{TPO}\right)$ profiles over fresh (a) and $\mathrm{H}_{2}$-pretreated (b) $10 \mathrm{wt} . \% \mathrm{Ag} / \mathrm{Al}_{2} \mathrm{O}_{3}$ catalysts. Reaction conditions: $\mathrm{NH}_{3}, 500 \mathrm{ppm}$; $\mathrm{O}_{2}, 10$ vol.\%; He as carrier; flow rate, $100 \mathrm{~cm}^{3} \mathrm{~min}^{-1}$; catalyst weight, $0.1 \mathrm{~g}$ (W/ $\left.\mathrm{F}=0.06 \mathrm{~g} \mathrm{~s} \mathrm{~cm}^{-1}\right)$. 
desorbed over the fresh $\mathrm{Ag} / \mathrm{Al}_{2} \mathrm{O}_{3}$ (Fig. 1a) at temperatures from $50{ }^{\circ} \mathrm{C}$ to $300^{\circ} \mathrm{C}$. No product was formed below $140^{\circ} \mathrm{C}$. Upon heating, $\mathrm{N}_{2}$ was formed/desorbed as the main product from $160^{\circ} \mathrm{C}$ to $500{ }^{\circ} \mathrm{C} ; \mathrm{N}_{2} \mathrm{O}$ was the second main product detected in the temperature range $\left(160-350{ }^{\circ} \mathrm{C}\right)$, while at higher temperatures $\left(>350^{\circ} \mathrm{C}\right)$, significant amounts of NO were formed/desorbed. However, over the $\mathrm{H}_{2}$-pretreated $\mathrm{Ag} / \mathrm{Al}_{2} \mathrm{O}_{3}$ (Fig. 1b), $\mathrm{NH}_{3}$ desorbed mainly at low temperatures $\left(<160^{\circ} \mathrm{C}\right)$. The selectivity of products of $\mathrm{NH}_{3}-\mathrm{TPO}$ strongly depended on the reaction temperature. $\mathrm{N}_{2} \mathrm{O}$ and $\mathrm{N}_{2}$ were the main products detected in the low temperature range (80$160{ }^{\circ} \mathrm{C}$ ); $\mathrm{N}_{2}$ was found to be the main reaction product at temperatures above $160^{\circ} \mathrm{C}$, while at higher temperatures $\left(>350^{\circ} \mathrm{C}\right)$, significant amounts of $\mathrm{NO}$ were formed.

Compared to the fresh $\mathrm{Ag} / \mathrm{Al}_{2} \mathrm{O}_{3}, \mathrm{NH}_{3}$ could be oxidized at a lower temperature $\left(<140{ }^{\circ} \mathrm{C}\right)$ over the $\mathrm{H}_{2}$-pretreated $\mathrm{Ag} / \mathrm{Al}_{2} \mathrm{O}_{3}$. Most products of $\mathrm{NH}_{3}$ oxidation at low temperatures were $\mathrm{N}_{2} \mathrm{O}$ and $\mathrm{N}_{2}$. However, at higher temperatures, the main products of $\mathrm{NH}_{3}$ oxidization over the fresh and $\mathrm{H}_{2}$-pretreated $\mathrm{Ag} / \mathrm{Al}_{2} \mathrm{O}_{3}$ catalysts were similar. This demonstrates that $\mathrm{H}_{2}$ pretreatment enhances the low temperature activity of $\mathrm{NH}_{3}$ oxidation over $\mathrm{Ag}$ / $\mathrm{Al}_{2} \mathrm{O}_{3}$ and that the low temperature $\left(<140^{\circ} \mathrm{C}\right)$ products are different from those produced at higher temperatures.

\section{2. $\mathrm{O}_{2}$-pulse adsorption}

The effect of the $\mathrm{O}_{2}$-pulse adsorption on the fresh and $\mathrm{H}_{2}$-pretreated $\mathrm{Ag} / \mathrm{Al}_{2} \mathrm{O}_{3}$ catalysts was investigated to elucidate the $\mathrm{O}_{2}$ uptake of the catalysts at $100^{\circ} \mathrm{C}$ and $160^{\circ} \mathrm{C}$. As seen in Fig. 2, molecular $\mathrm{O}_{2}$ was readily chemisorbed on the $\mathrm{H}_{2}$-pretreated $\mathrm{Ag}$ / $\mathrm{Al}_{2} \mathrm{O}_{3}$; in contrast, little molecular $\mathrm{O}_{2}$ was adsorbed on the fresh $\mathrm{Ag} / \mathrm{Al}_{2} \mathrm{O}_{3}$.

Gang et al. [11,13] reported that adsorbed oxygen atom appeared on the reduced $\mathrm{Ag}$ catalysts, and the dissociation of $\mathrm{O}_{2}$ was believed to be the rate-controlling step for $\mathrm{NH}_{3}$ oxidation [13]. Lefferts et al. [18] also detected oxygen atom on a $\mathrm{H}_{2}$-pretreated $\mathrm{Ag}$ surface, and the molecular $\mathrm{O}_{2}$ was only present for a short time after removing air from the sample. Based on our $\mathrm{O}_{2}$ pulse adsorption results, we conclude that molecular $\mathrm{O}_{2}$ can be dissociatively chemisorbed on the surface of $\mathrm{H}_{2}$-pretreated $\mathrm{Ag} / \mathrm{Al}_{2} \mathrm{O}_{3}$

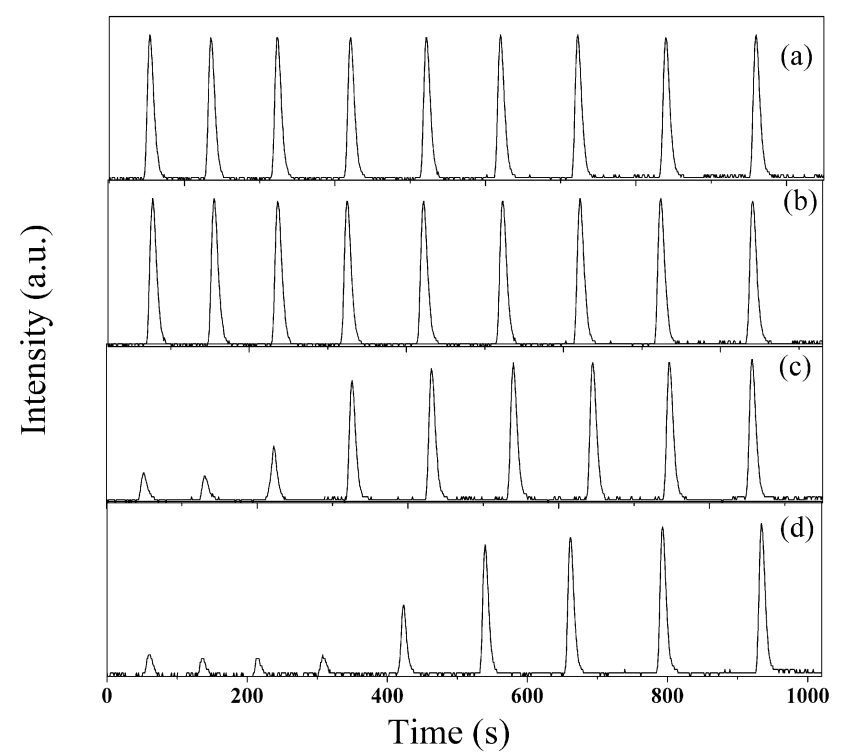

Fig. 2. $\mathrm{O}_{2}$ uptakes on fresh 10 wt.\% $\mathrm{Ag} / \mathrm{Al}_{2} \mathrm{O}_{3}$ and on $\mathrm{H}_{2}$-pretreated $10 \mathrm{wt} . \% \mathrm{Ag} / \mathrm{Al}_{2} \mathrm{O}_{3}$ at various temperatures. Fresh $10 \mathrm{wt} . \% \mathrm{Ag} / \mathrm{Al}_{2} \mathrm{O}_{3}: 100{ }^{\circ} \mathrm{C}$ (a), $160{ }^{\circ} \mathrm{C}$ (b); $\mathrm{H}_{2-}$ pretreated $10 \mathrm{wt} . \% \mathrm{Ag} / \mathrm{Al}_{2} \mathrm{O}_{3}: 100{ }^{\circ} \mathrm{C}$ (c); $160{ }^{\circ} \mathrm{C}$ (d). Reaction conditions: $\mathrm{O}_{2}$, $4.46 \mu \mathrm{mol} /$ pulse; He as carrier; flow rate, $40 \mathrm{~cm}^{3} \mathrm{~min}^{-1}$; catalyst weight, $0.3 \mathrm{~g}$.

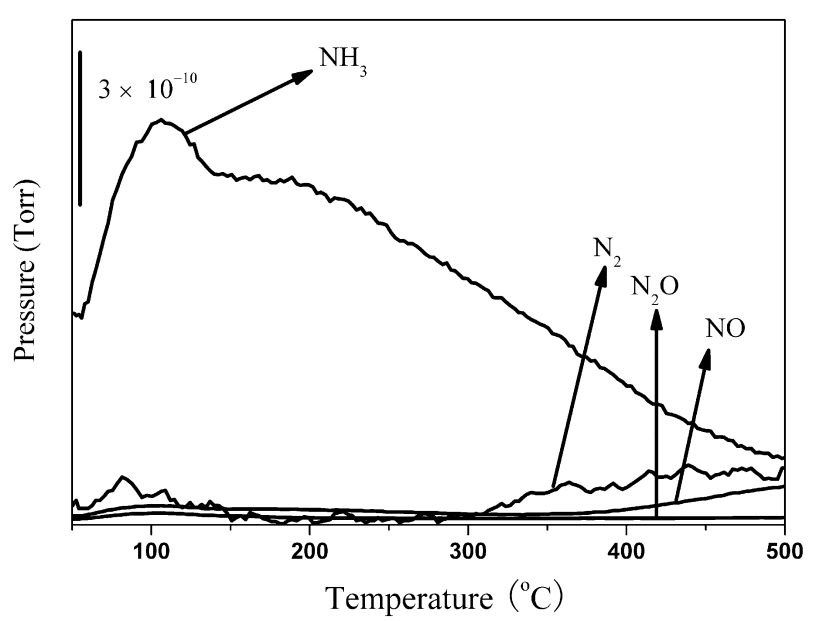

Fig. 3. $\mathrm{NH}_{3}-\mathrm{TPO}$ profiles over the fresh $10 \mathrm{wt} . \% \mathrm{Ag} / \mathrm{Al}_{2} \mathrm{O}_{3}$ catalyst, reaction conditions: $\mathrm{NH}_{3}, 500 \mathrm{ppm}$; He as carrier; flow rate, $100 \mathrm{~cm}^{3} \mathrm{~min}^{-1}$; catalyst weight, $0.1 \mathrm{~g}\left(\mathrm{~W} / \mathrm{F}=0.06 \mathrm{~g} \mathrm{~s} \mathrm{~cm}^{-1}\right)$.

to form $\mathrm{O}$ species, while molecular $\mathrm{O}_{2}$ cannot be adsorbed dissociatively on the surface of fresh $\mathrm{Ag} / \mathrm{Al}_{2} \mathrm{O}_{3}$. In conjunction with our TPO results mentioned above (Fig. 1), we found that the $\mathrm{NH}_{3}$ could be oxidized at a lower temperature $\left(<140{ }^{\circ} \mathrm{C}\right)$ over the $\mathrm{H}_{2}$-pretreated $\mathrm{Ag} / \mathrm{Al}_{2} \mathrm{O}_{3}$ in the presence of the chemisorbed oxygen atom. However, over the fresh $\mathrm{Ag} / \mathrm{Al}_{2} \mathrm{O}_{3}, \mathrm{NH}_{3}$ could also be oxidized at higher temperatures in the absence of $\mathrm{O}$. Because the molecular $\mathrm{O}_{2}$ could not be adsorbed on the fresh catalyst, the adsorbed $\mathrm{NH}_{3}$ mainly interacted with the gas phase $\mathrm{O}_{2}$ or the lattice oxygen under these conditions. According to our other TPO experiment over fresh Ag/ $\mathrm{Al}_{2} \mathrm{O}_{3}$ (Fig. 3) in the absence of gaseous $\mathrm{O}_{2}\left(\mathrm{NH}_{3}-\mathrm{He}\right.$ feed), we found that little product of $\mathrm{NH}_{3}$ oxidation was formed below $300{ }^{\circ} \mathrm{C}$. The adsorbed $\mathrm{NH}_{3}$ mainly reacts with the gas phase $\mathrm{O}_{2}$ over fresh $\mathrm{Ag} /$ $\mathrm{Al}_{2} \mathrm{O}_{3}$ in the presence of gaseous $\mathrm{O}_{2}$. This demonstrates that the oxygen species have a significant influence on the low temperature $\left(<140{ }^{\circ} \mathrm{C}\right)$ activity of $\mathrm{NH}_{3}$ oxidation over $\mathrm{Ag} / \mathrm{Al}_{2} \mathrm{O}_{3}$. This means that the dissociation of $\mathrm{O}_{2}$ is the rate-controlling step for $\mathrm{NH}_{3}$ oxidation.

$\mathrm{Ag}^{0}$ is the main $\mathrm{Ag}$ species on $\mathrm{H}_{2}$-pretreated $\mathrm{Ag} / \mathrm{Al}_{2} \mathrm{O}_{3}$, while $\mathrm{Ag}^{+}$ is the main $\mathrm{Ag}$ species on fresh $\mathrm{Ag} / \mathrm{Al}_{2} \mathrm{O}_{3}$ [17]. The presence of different $\mathrm{Ag}$ species on the catalyst clearly affects the chemisorption of $\mathrm{O}_{2}$. The presence of $\mathrm{Ag}^{\mathrm{O}}$ caused the adsorption of $\mathrm{O}$ species and must have been a reason for the enhanced low temperature activity of $\mathrm{NH}_{3}$ oxidation over $\mathrm{H}_{2}$-pretreated $\mathrm{Ag} / \mathrm{Al}_{2} \mathrm{O}_{3}$.

$\mathrm{O}_{2}$ uptake of $\mathrm{H}_{2}$-pretreated $\mathrm{Ag} / \mathrm{Al}_{2} \mathrm{O}_{3}$ at $160{ }^{\circ} \mathrm{C}\left(76.58 \mu \mathrm{mol} \mathrm{g}^{-1}\right)$ was higher than that at $100{ }^{\circ} \mathrm{C}\left(45.73 \mu \mathrm{mol} \mathrm{g}^{-1}\right)$. This demonstrates that the chemisorption of $\mathrm{O}_{2}$ on $\mathrm{Ag} / \mathrm{Al}_{2} \mathrm{O}_{3}$ is affected by temperature, in agreement with other reports $[11,18,19]$.

\subsection{FTIR study of $\mathrm{NH}_{3}$ adsorption}

FTIR spectra of the adsorbed species due to contact with the fresh and $\mathrm{H}_{2}$-pretreated $10 \mathrm{wt} . \% \mathrm{Ag} / \mathrm{Al}_{2} \mathrm{O}_{3}$ catalysts at different temperatures with $\mathrm{NH}_{3}$ are presented in Figs. 4 and 5. As shown in Fig. 4, after the sample was treated with $\mathrm{NH}_{3}$ at room temperature, the bands were observed at $1695,1614,1483,1389$, and $1232 \mathrm{~cm}^{-1}$. The bands at 1695 and $1483 \mathrm{~cm}^{-1}$ were due to the asymmetric and symmetric deformation modes of $\mathrm{NH}_{3}$ coordinated on Brønsted acid sites $\left(\mathrm{NH}_{4}^{+}\right)$[6,20-23], respectively. The band at $1389 \mathrm{~cm}^{-1}$ was observed under similar conditions on $\mathrm{Ni} /$ $\mathrm{Al}_{2} \mathrm{O}_{3}$ by Amblard et al. [6] and on $\mathrm{Au} / \mathrm{MO}_{x} / \gamma-\mathrm{Al}_{2} \mathrm{O}_{3}$ by Lin et al. [24]. According to the literature $[6,24]$ and the peak behavior when the sample was heated, the band at $1389 \mathrm{~cm}^{-1}$ could be assigned to $\mathrm{NH}_{4}^{+}$ad-species on the $\gamma-\mathrm{Al}_{2} \mathrm{O}_{3}$ support. The bands at 1614 and $1232 \mathrm{~cm}^{-1}$ could be assigned to the asymmetric and symmetric 


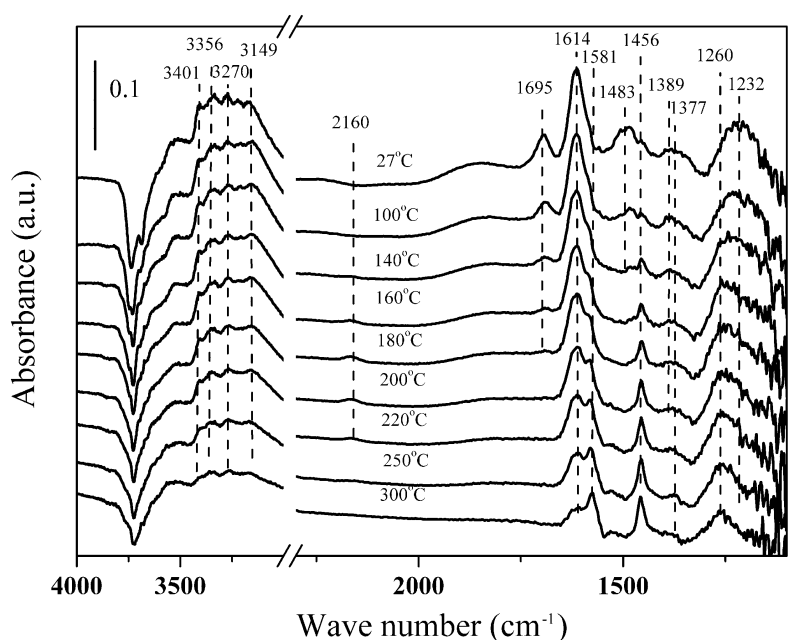

Fig. 4. FTIR spectra of the adsorbed species arising from contact of $\mathrm{NH}_{3}(500 \mathrm{ppm})$ with the fresh $10 \mathrm{wt} . \% \mathrm{Ag} / \mathrm{Al}_{2} \mathrm{O}_{3}$ at room temperature and successive purging with $\mathrm{N}_{2}$ at various temperatures.

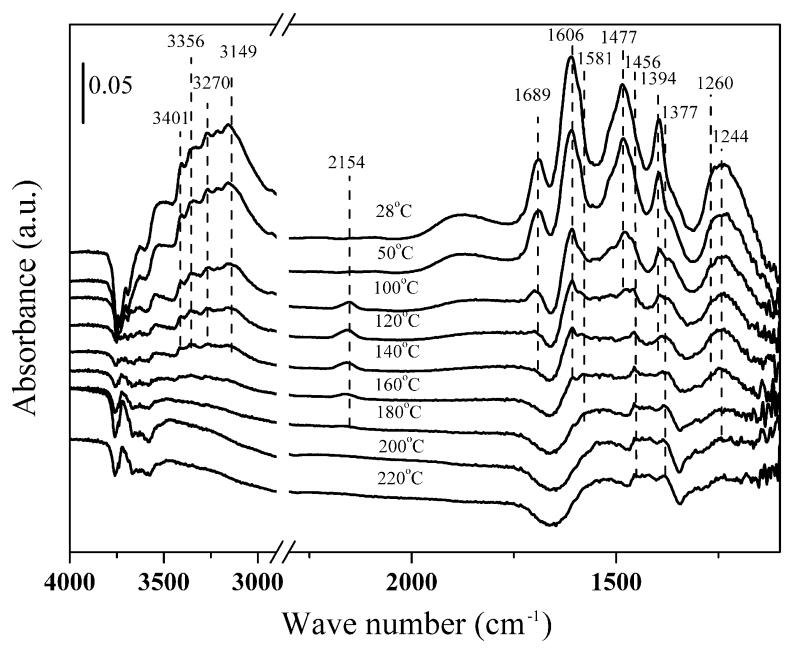

Fig. 5. FTIR spectra of the adsorbed species arising from contact of $\mathrm{NH}_{3}(500 \mathrm{ppm})$ with the $\mathrm{H}_{2}$-pretreated $10 \mathrm{wt} . \% \mathrm{Ag} / \mathrm{Al}_{2} \mathrm{O}_{3}$ at room temperature and successive purging with $\mathrm{N}_{2}$ at various temperatures.

deformation modes of $\mathrm{NH}_{3}$ coordinated on Lewis acid sites [6,2023], respectively. Correspondingly, the bands in the $\mathrm{NH}$ stretching region were also observed at $3401,3356,3270$, and $3149 \mathrm{~cm}^{-1}$ $[8,14,25]$.

The intensities of these bands decreased gradually with the increase in the sample temperature (Fig. 4). Upon heating, first, the bands of $\mathrm{NH}_{3}$ coordinated on Brønsted acid sites disappeared, followed by the bands ascribed to $\mathrm{NH}_{3}$ coordinated on Lewis acid sites. This desorption sequence seemed to coincide with the expected adsorption strength of these ad-species. The $\mathrm{NH}_{3}$ coordinated on Brønsted acid sites was weaker than that coordinated on Lewis acid sites. Desorption of the unreacted $\mathrm{NH}_{3}$ and the activation of $\mathrm{NH}_{3}$ were responsible for these decreases. A new weak band was visible at $2160 \mathrm{~cm}^{-1}$ from $160{ }^{\circ} \mathrm{C}$ to $220^{\circ} \mathrm{C}$, but vanished at temperatures above $220^{\circ} \mathrm{C}$. The assignment of this new peak will be discussed in the following section.

With increasing temperatures, intensities of three bands, 1581, 1456 , and $1377 \mathrm{~cm}^{-1}$, increased following the decrease of the bands assignable to $\mathrm{NH}_{3}$. The bands at 1581 and $1377 \mathrm{~cm}^{-1}$ were assigned to amide $\left(-\mathrm{NH}_{2}\right)$ scissorings and $\left(-\mathrm{NH}_{2}\right)$ waggings, respectively. The band at $1456 \mathrm{~cm}^{-1}$ was ascribed to -NH deformation modes $[8,14,24,25]$. These results indicate that upon heating, the adsorbed $\mathrm{NH}_{3}$ can be activated to form $-\mathrm{NH}_{2}$ and - $\mathrm{NH}$ intermediates through abstraction of hydrogen.

$\mathrm{NH}_{3} \rightarrow \mathrm{NH}_{2}+\mathrm{H}$
$\mathrm{NH}_{2} \rightarrow \mathrm{NH}+\mathrm{H}$

The same experiment was performed on the $\mathrm{H}_{2}$-pretreated $\mathrm{Ag}$ / $\mathrm{Al}_{2} \mathrm{O}_{3}$ catalyst. Similar bands at $1689,1606,1477,1394$, and $1244 \mathrm{~cm}^{-1}$ were observed after $\mathrm{NH}_{3}$ adsorption (Fig. 5). Upon heating, the bands of $\mathrm{NH}_{3}$ coordinated on Brønsted acid sites disappeared, followed by the bands ascribed to $\mathrm{NH}_{3}$ coordinated on Lewis acid sites, and finally the band of $-\mathrm{NH}$. A new weak band at $2154 \mathrm{~cm}^{-1}$ was observed from $100^{\circ} \mathrm{C}$ to $160{ }^{\circ} \mathrm{C}$, which disappeared at temperatures above $160^{\circ} \mathrm{C}$.

The bands at $2222 \mathrm{~cm}^{-1}$ are reportedly due to $\mathrm{N}-\mathrm{N}$ stretching modes of gas phase $\mathrm{N}_{2} \mathrm{O}$ over the reduced $\mathrm{Ag}$ catalyst [26]. A similar band at $2200 \mathrm{~cm}^{-1}$ upon $\mathrm{NH}_{3}$ oxidation on $\mathrm{ZnO}$ has been assigned to adsorbed $\mathrm{N}_{2} \mathrm{O}$ [27]. The appearance of more than one form of adsorbed $\mathrm{N}_{2} \mathrm{O}$ is often explained by the simultaneous presence of $\mathrm{N}$ - and $\mathrm{O}$-bonded molecules and/or by adsorption on different sites. However, the $\mathrm{N}-\mathrm{O}$ modes of $\mathrm{N}_{2} \mathrm{O}$ were not observable in many cases because of the strong bands associated with the substrate. When the $\mathrm{N}-\mathrm{O}$ modes of adsorbed $\mathrm{N}_{2} \mathrm{O}$ were detected, they were registered in the $1262-1220 \mathrm{~cm}^{-1}$ region [28]. As shown in Figs. 4 and 5, a band was observable at $1260 \mathrm{~cm}^{-1}$, but it did not disappear synchronously with the band at $2160 \mathrm{~cm}^{-1}$; hence these two bands should not be assigned to one ad-species. The band at $1260 \mathrm{~cm}^{-1}$ might be due to the shift in the band of $\mathrm{NH}_{3}$ coordinated at Lewis acid sites $\left(1244,1232 \mathrm{~cm}^{-1}\right)$.

To assure the correct assignment of the band (2154, $2160 \mathrm{~cm}^{-1}$ ), we investigated the interaction of $\mathrm{N}_{2} \mathrm{O}$ and $\mathrm{Ag} / \mathrm{Al}_{2} \mathrm{O}_{3}$ (the results are shown in Supplementary material). We found that the bands in the $2150-2300 \mathrm{~cm}^{-1}$ region were observable due to the asymmetric $\mathrm{N}-\mathrm{N}-\mathrm{O}$ stretching modes of gas phase $\mathrm{N}_{2} \mathrm{O}$, but they disappeared quickly after purging with $\mathrm{N}_{2}$ for several minutes. Therefore, the band at $2154(2160) \mathrm{cm}^{-1}$ should not be assigned to the gas phase $\mathrm{N}_{2} \mathrm{O}$ over the $\mathrm{Ag} / \mathrm{Al}_{2} \mathrm{O}_{3}$. Our results suggest that this band $\left(2154,2160 \mathrm{~cm}^{-1}\right)$ should be assigned to adsorbed $\mathrm{N}_{2} \mathrm{O}$.

Compared to the results on the fresh $\mathrm{Ag} / \mathrm{Al}_{2} \mathrm{O}_{3}$ (Fig. 4), the bands of $\mathrm{NH}_{3}$ adsorbed on Brønsted and Lewis acid sites of the $\mathrm{H}_{2}$-pretreated $\mathrm{Ag} / \mathrm{Al}_{2} \mathrm{O}_{3}$ disappeared at lower temperatures. While the intensity of these bands decreased with a reduction in temperature, the bands of $-\mathrm{NH}_{2}\left(1581,1377 \mathrm{~cm}^{-1}\right)$ and $-\mathrm{NH}\left(1456 \mathrm{~cm}^{-1}\right)$ appeared, indicating that $\mathrm{NH}_{3}$ adsorbed on $\mathrm{H}_{2}$-pretreated $\mathrm{Ag}$ / $\mathrm{Al}_{2} \mathrm{O}_{3}$ can be activated to form $-\mathrm{NH}_{2}$ and $-\mathrm{NH}$ intermediates at lower temperatures. Together with our $\mathrm{O}_{2}$-pulse adsorption results (Fig. 2), this indicates that both adsorbed $\mathrm{NH}_{3}$ and $\mathrm{O}_{2}$ can be activated at lower temperatures $\left(<140^{\circ} \mathrm{C}\right)$ on $\mathrm{H}_{2}$-pretreated $\mathrm{Ag} /$ $\mathrm{Al}_{2} \mathrm{O}_{3}$, which may explain the enhanced low temperature activity of $\mathrm{NH}_{3}$ oxidation.

\subsection{FTIR study of the interaction of $\mathrm{NH}_{3}$ with $\mathrm{O}_{2}$}

The $\mathrm{NH}_{3}$ oxidation mechanism was studied with respect to the behavior of adsorbed $\mathrm{NH}_{3}$ species interacting with $\mathrm{O}_{2}$ on the surfaces of fresh and $\mathrm{H}_{2}$-pretreated $10 \mathrm{wt} \% \mathrm{Ag} / \mathrm{Al}_{2} \mathrm{O}_{3}$ catalysts using in situ DRIFTS. Fig. 6 shows the in situ DRIFT spectra of the fresh $\mathrm{Ag} / \mathrm{Al}_{2} \mathrm{O}_{3}$ in a flow of $\mathrm{NH}_{3}+\mathrm{O}_{2}$ at various temperatures. The bands of $\mathrm{NH}_{3}$ coordinated on Brønsted acid sites $\left(1691,1487,1389 \mathrm{~cm}^{-1}\right)$ disappeared at temperatures above $140{ }^{\circ} \mathrm{C}$. However, the bands coordinated on Lewis acid sites $\left(1614,1232 \mathrm{~cm}^{-1}\right)$ decreased gradually and vanished at higher temperatures $\left(>220^{\circ} \mathrm{C}\right)$. While these band intensities decreased, the band intensity of $-\mathrm{NH}$ $\left(1456 \mathrm{~cm}^{-1}\right)$ increased from $100{ }^{\circ} \mathrm{C}$. Three new bands appeared at 


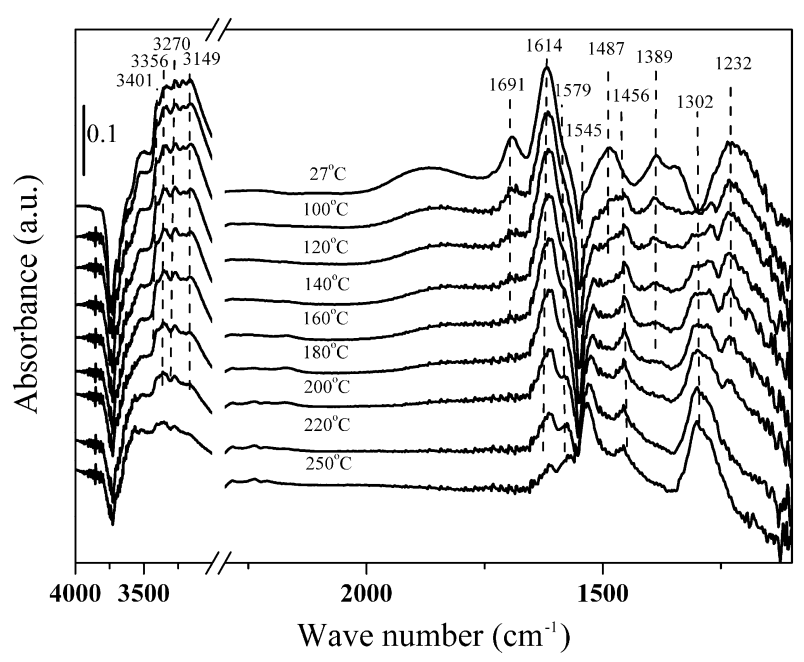

Fig. 6. FTIR spectra of the fresh $10 \mathrm{wt} . \% \mathrm{Ag} / \mathrm{Al}_{2} \mathrm{O}_{3}$ catalyst treated with a flow of $500 \mathrm{ppm} \mathrm{NH} \mathrm{NH}_{3}+10$ vol.\% $\mathrm{O}_{2} / \mathrm{N}_{2}$ at various temperatures.

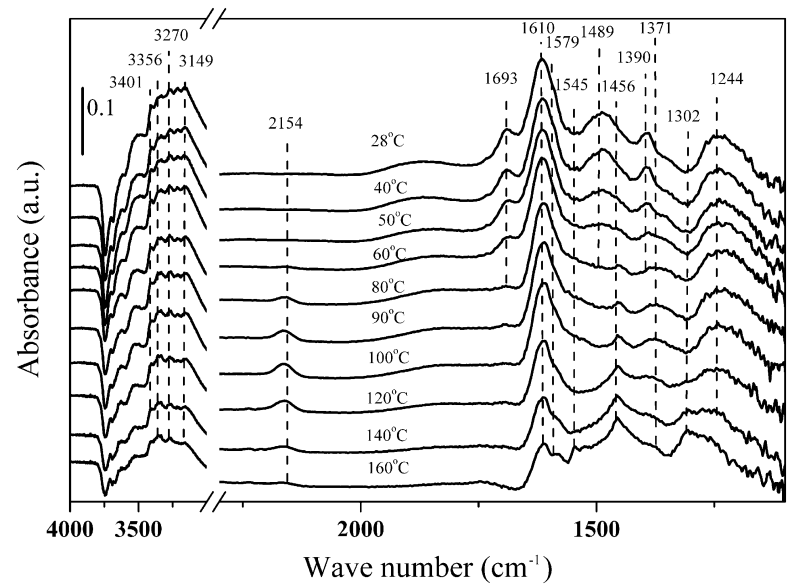

Fig. 7. FTIR spectra of the $\mathrm{H}_{2}$-pretreated $10 \mathrm{wt} . \% \mathrm{Ag} / \mathrm{Al}_{2} \mathrm{O}_{3}$ catalyst treated with a flow of $500 \mathrm{ppm} \mathrm{NH}_{3}+10$ vol.\% $\mathrm{O}_{2} / \mathrm{N}_{2}$ at various temperatures.

1576,1545 , and $1302 \mathrm{~cm}^{-1}$ at temperatures above $140{ }^{\circ} \mathrm{C}$ and increased significantly with rising temperature. These bands could be assigned to nitrate ad-species [28,29], and the assignments of different nitrates are discussed in a more detailed manner in the following section.

Fig. 7 shows the results of the similar experiment performed on the $\mathrm{H}_{2}$-pretreated $\mathrm{Ag} / \mathrm{Al}_{2} \mathrm{O}_{3}$. The bands of $\mathrm{NH}_{3}$ coordinated on Brønsted acid sites and Lewis acid sites decreased at a lower temperature in the presence of $\mathrm{O}_{2}$ than without $\mathrm{O}_{2}$ (Fig. 5). The $-\mathrm{NH}$ band $\left(1456 \mathrm{~cm}^{-1}\right)$ appeared at $80^{\circ} \mathrm{C}$ and increased significantly at temperatures above $140{ }^{\circ} \mathrm{C}$. The band of adsorbed $\mathrm{N}_{2} \mathrm{O}$ $\left(2154 \mathrm{~cm}^{-1}\right)$ was visible from $80^{\circ} \mathrm{C}$ to $140{ }^{\circ} \mathrm{C}$. In addition, it could be noted that the band assigned to nitrate ad-species (1302, $1579 \mathrm{~cm}^{-1}$ ) appeared at $140{ }^{\circ} \mathrm{C}$. The bands at $1579,1545,1456$, and $1302 \mathrm{~cm}^{-1}$ increased significantly when the temperature rose to $160^{\circ} \mathrm{C}$, demonstrating that at higher temperatures $\left(>140{ }^{\circ} \mathrm{C}\right)$ some nitrate ad-species are formed on the $\mathrm{H}_{2}$-pretreated $\mathrm{Ag} /$ $\mathrm{Al}_{2} \mathrm{O}_{3}$, similar to the results found on the fresh $\mathrm{Ag} / \mathrm{Al}_{2} \mathrm{O}_{3}$ (Fig. 6). However, on the fresh $\mathrm{Ag} / \mathrm{Al}_{2} \mathrm{O}_{3}$ (Fig. 6), no $\mathrm{N}_{2} \mathrm{O}\left(2154 \mathrm{~cm}^{-1}\right)$ adspecies appeared with the $-\mathrm{NH}$ band $\left(1456 \mathrm{~cm}^{-1}\right)$ at low temperatures $\left(<140^{\circ} \mathrm{C}\right)$. Based on these findings, together with the TPO results (Fig. 1), we conclude that the adsorbed $\mathrm{NH}_{3}$ could be activated to form $-\mathrm{NH}$ and further be converted to produce $\mathrm{N}_{2}$ and $\mathrm{N}_{2} \mathrm{O}$ on the $\mathrm{H}_{2}$-pretreated $\mathrm{Ag} / \mathrm{Al}_{2} \mathrm{O}_{3}$ at low temperatures $\left(<140{ }^{\circ} \mathrm{C}\right.$; Fig. 7). In contrast, no adsorbed $\mathrm{NH}_{3}$ was oxidized on the fresh $\mathrm{Ag} / \mathrm{Al}_{2} \mathrm{O}_{3}$ under this condition, although it could have been activated to form some $-\mathrm{NH}$ intermediates (Fig. 6).

The presence of surface - $\mathrm{NH}$ indicates the dissociative adsorption of $\mathrm{NH}_{3}$ and/or the presence of $\mathrm{H}$-abstraction on the surface. Our DRIFT results (Fig. 7) showed that at lower temperatures, the bands of adsorbed $\mathrm{NH}_{3}$ were smaller in the presence of $\mathrm{O}_{2}$ than without $\mathrm{O}_{2}$ (Fig. 5). Considering that gas phase $\mathrm{O}_{2}$ can be chemisorbed as oxygen atom on the surface of $\mathrm{H}_{2}$-pretreated $\mathrm{Ag} / \mathrm{Al}_{2} \mathrm{O}_{3}$, this indicates that the adsorbed $\mathrm{NH}_{3}$ is more readily activated to form $-\mathrm{NH}$ in the presence of oxygen atom, confirming the previous reports [1]. The first elementary process in $\mathrm{NH}_{3}$ oxidation on $\mathrm{H}_{2}$ pretreated $\mathrm{Ag} / \mathrm{Al}_{2} \mathrm{O}_{3}$ is likely the reaction of $\mathrm{NH}_{3}$ with $\mathrm{O}$ as follows:

$\mathrm{NH}_{3}+\mathrm{O} \rightarrow \mathrm{NH}+\mathrm{H}_{2} \mathrm{O}$

As shown in Fig. 7, $-\mathrm{NH}$ and the adsorbed $\mathrm{N}_{2} \mathrm{O}$ bands were visible at low temperatures $\left(<140{ }^{\circ} \mathrm{C}\right)$; some nitrate ad-species were observed at temperatures above $140{ }^{\circ} \mathrm{C}$, as seen on the fresh $\mathrm{Ag} /$ $\mathrm{Al}_{2} \mathrm{O}_{3}$ (Fig. 6). This clearly shows that over the $\mathrm{H}_{2}$-pretreated $\mathrm{Ag}$ / $\mathrm{Al}_{2} \mathrm{O}_{3},-\mathrm{NH}$ is the key intermediate of $\mathrm{NH}_{3}$ oxidation at low temperatures $\left(<140{ }^{\circ} \mathrm{C}\right)$, and the SCO pathway at low temperatures is different from the reaction route at temperatures above $140{ }^{\circ} \mathrm{C}$. In contrast, at temperatures above $140{ }^{\circ} \mathrm{C}$, the $\mathrm{SCO}$ of $\mathrm{NH}_{3}$ over fresh and $\mathrm{H}_{2}$-pretreated $\mathrm{Ag} / \mathrm{Al}_{2} \mathrm{O}_{3}$ catalysts both follow a similar reaction route.

A key role of - $\mathrm{NH}$ and - $\mathrm{HNO}$ species in $\mathrm{NH}_{3}$ oxidation was proposed by Zawadzki [1] and supported by Germain and Perez [30]. Zawadzki [1] suggested that on Pt or metal oxide catalysts, the -NH could interact with oxygen atom to form -HNO species; then the $-\mathrm{NH}$ and - HNO could react with each other giving rise to $\mathrm{N}_{2}$, while two - HNO species would be intermediates in $\mathrm{N}_{2} \mathrm{O}$ formation. However, we found no band assignable to -HNO (Fig. 7), perhaps because the $-\mathrm{HNO}$ reacted quickly.

To discover the - HNO species, the concentration of $\mathrm{NH}_{3}$ was reduced to lower the reaction rate. First, we evacuated the gaseous $\mathrm{NH}_{3}$ after exposure of the $\mathrm{H}_{2}$-pretreated $\mathrm{Ag} / \mathrm{Al}_{2} \mathrm{O}_{3}$ to $\mathrm{NH}_{3}$ for $1 \mathrm{~h}$ to leave the adsorbed $\mathrm{NH}_{3}$ on the surface of the catalyst. A flow of $\mathrm{O}_{2}$ was then supplied at various temperatures, and the subsequent spectra were collected (Fig. 8). Upon heating, $-\mathrm{NH}_{2}$ $\left(1371 \mathrm{~cm}^{-1}\right)$ and $-\mathrm{NH}\left(1456 \mathrm{~cm}^{-1}\right)$ appeared at temperatures above $70^{\circ} \mathrm{C}$; a new band was observed at $1529 \mathrm{~cm}^{-1}$ from $70{ }^{\circ} \mathrm{C}$ to $120^{\circ} \mathrm{C}$ (Fig. 8). Similar behavior was observed for adsorbed

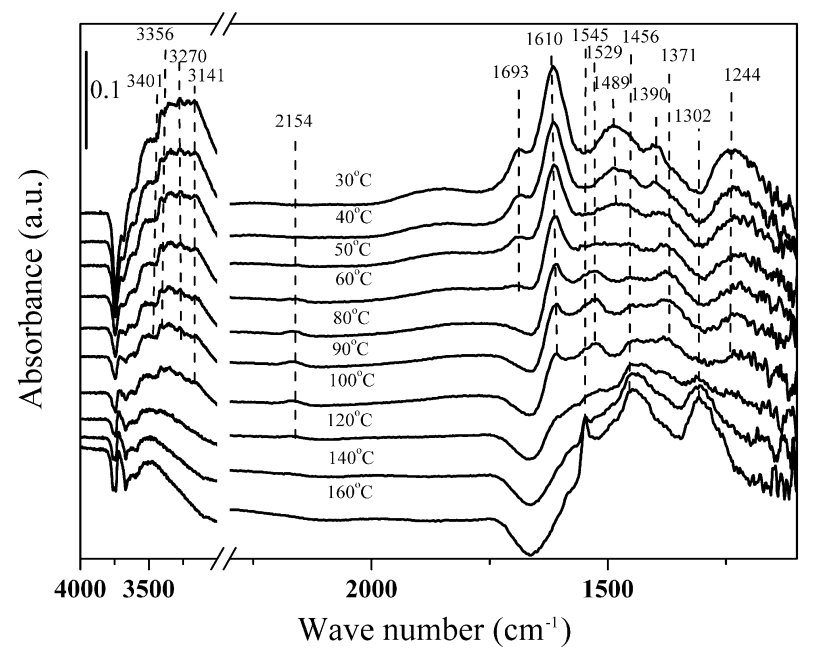

Fig. 8. FTIR spectra of the $\mathrm{H}_{2}$-pretreated $10 \mathrm{wt} . \% \mathrm{Ag} / \mathrm{Al}_{2} \mathrm{O}_{3}$ taken after adsorption of $\mathrm{NH}_{3}(500 \mathrm{ppm})$ at room temperature, followed by purging with $\mathrm{N}_{2}$ for 30 min and successive heating in $10 \mathrm{vol} . \% \mathrm{O}_{2} / \mathrm{N}_{2}$ at various temperatures. 


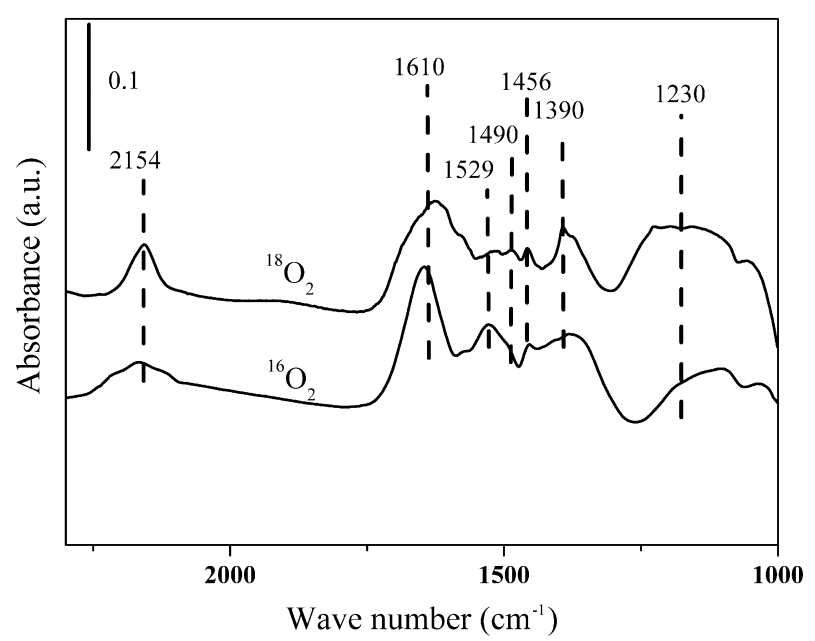

Fig. 9. FTIR spectra of the adsorbed $\mathrm{NH}_{3}$ interacting with the ${ }^{16} \mathrm{O}_{2}$ and ${ }^{18} \mathrm{O}_{2}$ over $\mathrm{H}_{2}$ pretreated $10 \mathrm{wt} . \% \mathrm{Ag} / \mathrm{Al}_{2} \mathrm{O}_{3}$ at $100{ }^{\circ} \mathrm{C}$ (The sample was exposed to $20 \mathrm{Torr} \mathrm{NH}_{3}$ for 30 min firstly, and then it was out gassed and exposed to 30 Torr $\mathrm{O}_{2}$ ).

$\mathrm{N}_{2} \mathrm{O}\left(2154 \mathrm{~cm}^{-1}\right)$ with a band at $1529 \mathrm{~cm}^{-1}$; this band may have been an intermediate in the formation of $\mathrm{N}_{2} \mathrm{O}$, and the peak at around $1529 \mathrm{~cm}^{-1}$ was near the reported NO stretching band of -HNO species $[7,8,24]$. Alternatively, -HNO could be responsible for two bands. The adsorbed - HNO species have been proposed to be responsible for a $\mathrm{N}=\mathrm{O}$ stretching band in the 1550 $1400 \mathrm{~cm}^{-1}$ range, and for a $-\mathrm{NH}$ bending band in the 1450 $1400 \mathrm{~cm}^{-1}$ region [7]. Since the two bands $\left(1529,1456 \mathrm{~cm}^{-1}\right)$ appear at the same time, this explanation is likely.

To help identify the -HNO species, the experiments were also conducted with ${ }^{18} \mathrm{O}_{2}$ and ${ }^{16} \mathrm{O}_{2}$ using FTIR. Fig. 9 illustrates the FTIR spectra obtained after either ${ }^{18} \mathrm{O}_{2}$ or ${ }^{16} \mathrm{O}_{2}$ interacting with the adsorbed $\mathrm{NH}_{3}$ on the $\mathrm{H}_{2}$-pretreated $\mathrm{Ag} / \mathrm{Al}_{2} \mathrm{O}_{3}$ catalyst at $100{ }^{\circ} \mathrm{C}$. The band near $1529 \mathrm{~cm}^{-1}$ after exposing to ${ }^{16} \mathrm{O}_{2}$ (Fig. 9) was red-shifted to around $1490 \mathrm{~cm}^{-1}$ after replacing with the ${ }^{18} \mathrm{O}_{2}$ (Fig. 9), which implies that this band is due to a species containing oxygen.

This implies that $-\mathrm{NH}$ may be converted to -HNO ad-species in the presence of $\mathrm{O}$ and that these ad-species must be the intermediates in the formation of $\mathrm{N}_{2}$ and $\mathrm{N}_{2} \mathrm{O}$ at low temperatures. At higher temperatures $\left(>140{ }^{\circ} \mathrm{C}\right)$, the bands of $-\mathrm{HNO}\left(1529 \mathrm{~cm}^{-1}\right)$ and adsorbed $\mathrm{N}_{2} \mathrm{O}\left(2154 \mathrm{~cm}^{-1}\right)$ vanished synchronously, while the bands of nitrates increased. This result indicates that the reaction route of $\mathrm{NH}_{3}$ oxidation over $\mathrm{Ag} / \mathrm{Al}_{2} \mathrm{O}_{3}$ is different in different temperature regions.

\subsection{FTIR study of $\mathrm{NO}+\mathrm{O}_{2}$ adsorption}

FTIR spectra of the adsorption of $\mathrm{NO}$ in the presence of $\mathrm{O}_{2}$ on the $\mathrm{H}_{2}$-pretreated $10 \mathrm{wt} . \% \mathrm{Ag} / \mathrm{Al}_{2} \mathrm{O}_{3}$ at $160{ }^{\circ} \mathrm{C}$ were observed to investigate the nitrate ad-species on the catalyst, and the results are shown in Fig. 10a. The bands at 1614, 1579, 1545, 1456, and $1302 \mathrm{~cm}^{-1}$ were detected. In addition, a weak band at $1750 \mathrm{~cm}^{-1}$ was also seen. Based on the previous studies of the $\mathrm{NO}+\mathrm{O}_{2}$ reaction on $\mathrm{Al}_{2} \mathrm{O}_{3}$ or $\mathrm{Ag} / \mathrm{Al}_{2} \mathrm{O}_{3}$ catalysts, these peaks were tentatively assigned to adsorbed $\mathrm{N}_{2} \mathrm{O}_{4}\left(1750 \mathrm{~cm}^{-1}\right)$ and monodentate $\left(1545 \mathrm{~cm}^{-1}\right)$, bidentate $\left(1579 \mathrm{~cm}^{-1}\right)$, and bridging $\left(1614 \mathrm{~cm}^{-1}\right) \mathrm{ni}-$ trates $[26,28,31-34]$. The bands at 1456 and $1302 \mathrm{~cm}^{-1}$ were close to the IR bands at 1411 and $1302 \mathrm{~cm}^{-1}$ for adsorbed water-solvated surface nitrates on $\mathrm{Al}_{2} \mathrm{O}_{3}$ [31]. Since the adsorbed water could be removed from the surface by purging with dry $\mathrm{N}_{2}$ at $160^{\circ} \mathrm{C}$, band intensity of the water-solvated surface nitrates
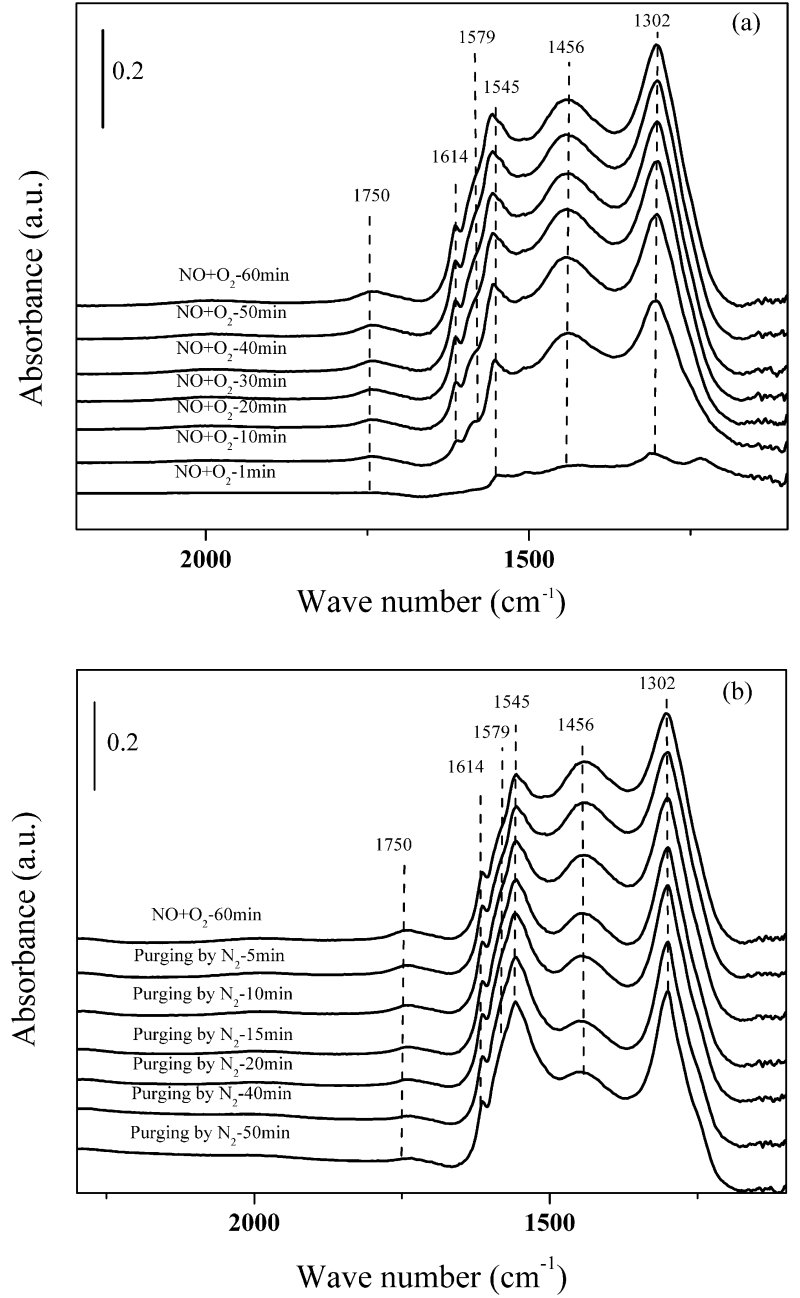

Fig. 10. FTIR spectra of the adsorbed species arising from $\mathrm{NO}+\mathrm{O}_{2}\left(500 \mathrm{ppm} \mathrm{NO}, \mathrm{O}_{2}\right.$ 10 vol.\%) adsorption over the $\mathrm{H}_{2}$-pretreated $10 \mathrm{wt} . \% \mathrm{Ag} / \mathrm{Al}_{2} \mathrm{O}_{3}$ at $160{ }^{\circ} \mathrm{C}$ (a) and after successive purging with $\mathrm{N}_{2}$ at $160{ }^{\circ} \mathrm{C}$ (b).

would decrease. According to our results (Fig. 10b), the band at $1456 \mathrm{~cm}^{-1}$ decreased significantly after purging with $\mathrm{N}_{2}$, while the band at $1302 \mathrm{~cm}^{-1}$ did not vary in intensity. Therefore, the band at $1456 \mathrm{~cm}^{-1}$ should be assigned to adsorbed water-solvated surface nitrate ad-species on $\mathrm{Ag} / \mathrm{Al}_{2} \mathrm{O}_{3}$. In addition, it could be noted that this band at $1456 \mathrm{~cm}^{-1}$ was in the same region as the - NH band. As shown in Fig. 7, -NH appeared at a lower temperature $\left(80^{\circ} \mathrm{C}\right)$ after $\mathrm{NH}_{3}$ activation, while the water-solvated surface nitrate ad-species were visible at a higher temperature $\left(160^{\circ} \mathrm{C}\right)$ going with other nitrate ad-species; therefore, they should be assigned to different ad-species at different temperatures. The band at $1302 \mathrm{~cm}^{-1}$ was also close to that of bidentate nitrate on $\mathrm{Ag} / \mathrm{Al}_{2} \mathrm{O}_{3}[32,33]$; thus we are inclined to assign this band to bidentate nitrate.

According to our FTIR spectra results on $\mathrm{NH}_{3}$ oxidation (Figs. 6 and 7), the bands assignable to nitrate ad-species (1614, 1579, 1545,1456 , and $1302 \mathrm{~cm}^{-1}$ ) appeared in the same regions as $\mathrm{NO}+\mathrm{O}_{2}$ ad-species. This result indicates that adsorbed $\mathrm{NH}_{3}$ could be oxidized to form $\mathrm{NO}$ and adsorbed as nitrate ad-species on the catalysts in the presence of $\mathrm{O}_{2}$.

It could be noted that a band $\left(1614 \mathrm{~cm}^{-1}\right)$ of bridging nitrates was located at the same position as the asymmetric deformation modes of $\mathrm{NH}_{3}$ coordinated on the Lewis acid sites, which may explain the appearance of this peak at higher temperatures while the 


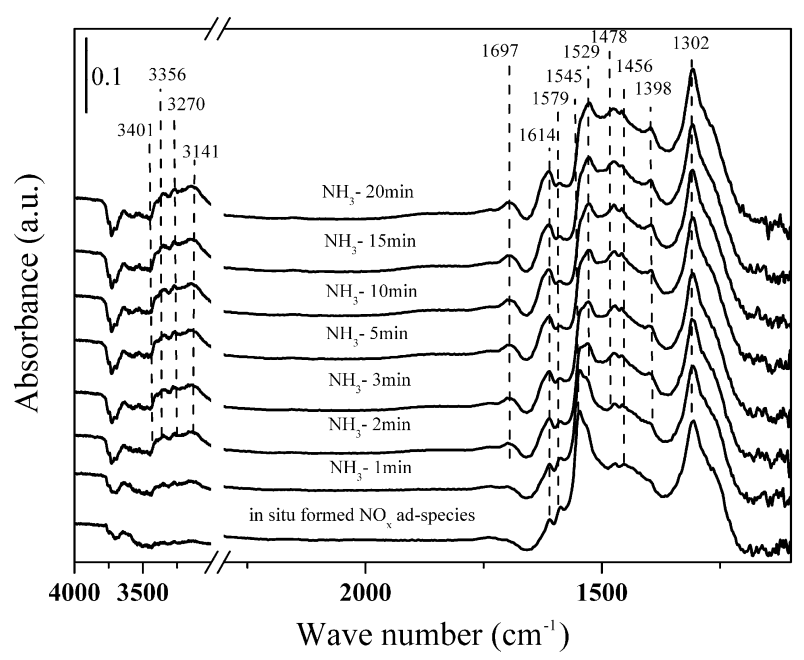

Fig. 11. FTIR spectra of the surface species arising from the interaction of $\mathrm{NH}_{3}$ $(500 \mathrm{ppm})$ with the in situ-formed $\mathrm{NO}_{x}$ on the $\mathrm{H}_{2}$-pretreated $10 \mathrm{wt} . \% \mathrm{Ag} / \mathrm{Al}_{2} \mathrm{O}_{3}$ at $160{ }^{\circ} \mathrm{C}$.

other bands $\left(1232,1244 \mathrm{~cm}^{-1}\right)$ of $\mathrm{NH}_{3}$ coordinated on the Lewis acid site disappeared (Figs. 6 and 7).

\subsection{Interaction of $\mathrm{NH}_{3}$ with the in situ-formed $\mathrm{NO}_{x}$}

To elucidate the reaction pathway, the interaction of $\mathrm{NH}_{3}$ with the in situ-formed $\mathrm{NO}_{x}$ species was investigated as follows: first, $\mathrm{NO}_{x}$ ad-species were formed in situ on the $\mathrm{H}_{2}$-pretreated $\mathrm{Ag}$ / $\mathrm{Al}_{2} \mathrm{O}_{3}$ by exposing the catalyst to $\mathrm{NH}_{3}$ and $\mathrm{O}_{2}$ at $160{ }^{\circ} \mathrm{C}$ for $1 \mathrm{~h}$. Then the sample was purged with $\mathrm{N}_{2}$ at this temperature for $0.5 \mathrm{~h}$. Finally, 500 ppm of $\mathrm{NH}_{3}$ was introduced when the in situ DRIFTS spectra were recorded. As shown in Fig. 11, the bands attributable to nitrate ad-species $\left(1614,1579,1545,1456,1302 \mathrm{~cm}^{-1}\right.$ ) were observed after exposing the $\mathrm{Ag} / \mathrm{Al}_{2} \mathrm{O}_{3}$ to $\mathrm{NH}_{3}$ and $\mathrm{O}_{2}$ at $160{ }^{\circ} \mathrm{C}$ for a brief period. Following $\mathrm{NH}_{3}$ inflow for $1 \mathrm{~min}$, the monodentate nitrate band $\left(1545 \mathrm{~cm}^{-1}\right)$ vanished, indicating that $\mathrm{NH}_{3}$ reacted with the $\mathrm{NO}_{x}$ ad-species quickly. However, the intensity of the bands $\left(1579,1302 \mathrm{~cm}^{-1}\right)$ attributable to bidentate nitrates only decreased slightly during this period. Therefore, we conclude that $\mathrm{NO}_{x}$ adsorbed as monodentate nitrate reacted more favorably with $\mathrm{NH}_{x}$ compared to the other nitrate ad-species. This result clearly indicates that the $\mathrm{SCO}$ of $\mathrm{NH}_{3}$ on the $\mathrm{H}_{2}$-pretreated $\mathrm{Ag} / \mathrm{Al}_{2} \mathrm{O}_{3}$ at this temperature follows an iSCR mechanism, which involves the oxidation of a significant percentage of $\mathrm{NH}_{3}$ into $\mathrm{NO}_{x}$ species, along with adsorbed $\mathrm{NO}_{x}$ species interacting with $\mathrm{NH}_{x}$ and being reduced to $\mathrm{N}_{2}$ with $\mathrm{N}_{2} \mathrm{O}$ as a by-product. The in situ-formed $\mathrm{NO}$ is the intermediate of this iSCR mechanism.

The bands assignable to $\mathrm{NH}_{3}$ ad-species (1697, 1614, 1478, and $1398 \mathrm{~cm}^{-1}$ ) appeared on $\mathrm{Ag} / \mathrm{Al}_{2} \mathrm{O}_{3}$ following $\mathrm{NH}_{3}$ inflow, as shown in Fig. 11. Their intensity increased with the exposure time. However, the bands at 1529 and $1456 \mathrm{~cm}^{-1}$ assignable to -HNO species increased at the same time. Together with our results mentioned above, this indicates that the adsorbed - $\mathrm{NH}$ might have interacted with the previously adsorbed surface $\mathrm{O}$ to form -HNO species under this condition.

\section{Discussion}

\section{1. $\mathrm{NH}_{3}$ adsorption}

As shown in Figs. 4 and 5, with the adsorption of $\mathrm{NH}_{3}$ and an increase in temperature, $-\mathrm{NH}_{2}$ and $-\mathrm{NH}$ intermediates appeared and the bands assignable to adsorbed $\mathrm{N}_{2} \mathrm{O}\left(2160,2154 \mathrm{~cm}^{-1}\right)$ were observed in the absence of $\mathrm{O}_{2}$. Other studies have found that in the absence of $\mathrm{O}_{2}$, activated - $\mathrm{NH}$ could also interact with lattice oxygen $\left(\mathrm{O}^{2-}\right)$ to produce a small quantity of $\mathrm{N}_{2} \mathrm{O}[7,8,14]$. Our results (Figs. 4 and 5) demonstrate that in the absence of $\mathrm{O}_{2}, \mathrm{NH}_{3}$ can dehydrogenate to form $-\mathrm{NH}_{2}$ and $-\mathrm{NH}$ intermediates and produce some products; however, this kind of reaction would not be sustainable under $\mathrm{O}_{2}$-free conditions and will not be discussed here in detail.

Based on the in situ DRIFTS results of $\mathrm{NH}_{3}$ oxidation (Fig. 6) on the surface of fresh $\mathrm{Ag} / \mathrm{Al}_{2} \mathrm{O}_{3}$, the bands of $\mathrm{NH}_{3}$ coordinated on Brønsted acid sites disappeared at $140{ }^{\circ} \mathrm{C}$, while the bands coordinated on Lewis acid sites decreased gradually at higher temperatures. However, our $\mathrm{NH}_{3}$-TPO (Fig. 1) and in situ DRIFTS (Fig. 6) results showed that over the fresh catalyst, the adsorbed $\mathrm{NH}_{3}$ could hardly be oxidized at low temperatures $\left(<140{ }^{\circ} \mathrm{C}\right)$. Therefore, the $\mathrm{NH}_{3}$ coordinated on Brønsted acid sites had no influence on the activity; only the $\mathrm{NH}_{3}$ coordinated on Lewis acid sites contributed to this reaction activity. A similar result was found on the $\mathrm{H}_{2}$-pretreated $\mathrm{Ag} / \mathrm{Al}_{2} \mathrm{O}_{3}$ (Fig. 7). These results indicate that Brønsted acid sites are not necessary for $\mathrm{NH}_{3}$ oxidation, in agreement with the previous findings in the literature $[7,8,14]$.

\subsection{Interaction of $\mathrm{NH}_{3}$ with $\mathrm{O}_{2}$}

\subsubsection{Interaction of $\mathrm{NH}_{3}$ with $\mathrm{O}_{2}$ at low temperatures $\left(<140{ }^{\circ} \mathrm{C}\right)$}

It has been (Figs. 7 and 8 ) demonstrated that the reaction pathway at low temperatures $\left(<140{ }^{\circ} \mathrm{C}\right)$ over $\mathrm{H}_{2}$-pretreated $\mathrm{Ag} / \mathrm{Al}_{2} \mathrm{O}_{3}$ is totally different from the route at temperatures above $140^{\circ} \mathrm{C}$. Oxygen atom has been found to be chemisorbed on the surface of $\mathrm{H}_{2}$ pretreated $\mathrm{Ag} / \mathrm{Al}_{2} \mathrm{O}_{3}$, and it is more active than the gaseous $\mathrm{O}_{2}$ or lattice oxygen $\left(\mathrm{O}^{2-}\right)$. At low temperatures $\left(<140{ }^{\circ} \mathrm{C}\right)$, $\mathrm{O}$ reacts more favorably with-NH to form -HNO intermediates (Fig. 8). The $-\mathrm{NH}$ and $-\mathrm{HNO}$ are the key intermediates of the $-\mathrm{NH}$ mechanism. $\mathrm{Za}-$ wadzki [1] previously proposed the $-\mathrm{NH}$ mechanism, but provided no evidence of the - $\mathrm{NH}$ and - $\mathrm{HNO}$ intermediates or $\mathrm{O}_{2}$ chemisorption. Since both the $\mathrm{O}_{2}$ chemisorption and the intermediates of $\mathrm{NH}$ and -HNO were detected in our experiments, we are inclined to attribute the low temperature reaction pathway of $\mathrm{NH}_{3}$ oxidation over $\mathrm{Ag} / \mathrm{Al}_{2} \mathrm{O}_{3}$ to the $-\mathrm{NH}$ mechanism. The main reaction routes at low temperatures $\left(<140{ }^{\circ} \mathrm{C}\right)$ are as follows:

$$
\begin{aligned}
& \mathrm{O}_{2} \rightarrow 2 \mathrm{O} \\
& \mathrm{NH}+\mathrm{O} \rightarrow \mathrm{HNO} \\
& \mathrm{NH}+\mathrm{HNO} \rightarrow \mathrm{N}_{2}+\mathrm{H}_{2} \mathrm{O} \\
& \mathrm{HNO}+\mathrm{HNO} \rightarrow \mathrm{N}_{2} \mathrm{O}+\mathrm{H}_{2} \mathrm{O}
\end{aligned}
$$

\subsubsection{Interaction of $\mathrm{NH}_{3}$ with $\mathrm{O}_{2}$ at high temperatures $\left(>140{ }^{\circ} \mathrm{C}\right)$}

At higher temperatures $\left(>140^{\circ} \mathrm{C}\right), \mathrm{NH}_{3}$ oxidation over $\mathrm{H}_{2}$-pretreated $\mathrm{Ag} / \mathrm{Al}_{2} \mathrm{O}_{3}$ does not follow the $-\mathrm{NH}$ mechanism (Figs. 7 and 8) mentioned above. Under this condition $\left(>140{ }^{\circ} \mathrm{C}\right)$, the interaction of $\mathrm{NH}_{3}$ with $\mathrm{O}_{2}$ caused the formation of $\mathrm{NO}_{x}$ ad-species on the $\mathrm{Ag} / \mathrm{Al}_{2} \mathrm{O}_{3}$, and the in situ-formed $\mathrm{NO}_{x}$ species could react quickly with $\mathrm{NH}_{3}$ following $\mathrm{NH}_{3}$ inflow (Fig. 11). Ramis et al. [14] proposed an SCR route; i.e., in the presence of $\mathrm{NO}$, the $-\mathrm{NH}_{2}$ would react with $\mathrm{NO}$ to produce $\mathrm{N}_{2}$, and - NH would react with NO to produce $\mathrm{N}_{2} \mathrm{O}$ as a by-product. Zawadzki [1] also suggested that $-\mathrm{NH}$ would react with molecular $\mathrm{O}_{2}$ to produce NO at higher temperatures, but the author did not propose the in situ reaction between the NO and $-\mathrm{NH}_{x}$. Since the key intermediate $\left(\mathrm{NO}_{x}\right)$ of the SCR routes proposed by Ramis et al. [8,14,35-38] was detected in our experiment (Figs. 6 and 7), and the $\mathrm{NH}_{3}$ could rapidly react with the in situ-formed $\mathrm{NO}_{x}$ ad-species (Fig. 11), we are inclined to accept that the $\mathrm{NH}_{3}$ oxidation over $\mathrm{Ag} / \mathrm{Al}_{2} \mathrm{O}_{3}$ at higher temperatures $\left(>140{ }^{\circ} \mathrm{C}\right)$ follows the iSCR mechanism. The reaction pathways are as follows: 
$\mathrm{NH}+\mathrm{O}_{2} \rightarrow \mathrm{NO}+\mathrm{OH}$

$\mathrm{NH}_{2}+\mathrm{NO} \rightarrow \mathrm{N}_{2}+\mathrm{H}_{2} \mathrm{O}$

$\mathrm{NH}+\mathrm{NO} \rightarrow \mathrm{N}_{2} \mathrm{O}+\mathrm{H}$

$\mathrm{H}+\mathrm{OH} \rightarrow \mathrm{H}_{2} \mathrm{O}$

A possible role of molecular $\mathrm{O}_{2}$ in $\mathrm{NH}_{3}$ oxidation to produce $\mathrm{NO}_{x}$ has also been proposed in the literature $[1,8]$ but may require higher temperatures compared to the interaction of $\mathrm{NH}_{3}$ with oxygen atom, which is in agreement with our above-mentioned results.

We found that $\mathrm{O}_{2}$ could also be adsorbed dissociatively to form surface oxygen atom on $\mathrm{H}_{2}$-pretreated $\mathrm{Ag} / \mathrm{Al}_{2} \mathrm{O}_{3}$ at higher temperatures $\left(160^{\circ} \mathrm{C}\right.$; Fig. 2$)$, and the coverage of active oxygen species increases with an increase of temperature up to $160^{\circ} \mathrm{C}$. Fig. 8 shows that the adsorbed $\mathrm{NH}_{3}$ could be quickly activated to form - $\mathrm{NH}$ intermediates via reaction (3) in the presence of oxygen atom. However, at higher temperatures $\left(>140^{\circ} \mathrm{C}\right)$, the $-\mathrm{NH}$ mainly interacted with the oxygen species to form NO intermediates (Fig. 8). This demonstrates that the increase of the ratio $(\mathrm{O} / \mathrm{NH})$ favors the formation of $\mathrm{NO}$ at higher temperatures. We could infer that the adsorbed $\mathrm{NH}_{3}$ interacted with oxygen atom and gaseous $\mathrm{O}_{2}$ at the same time over $\mathrm{H}_{2}$-pretreated $\mathrm{Ag} / \mathrm{Al}_{2} \mathrm{O}_{3}$ at higher temperatures $\left(>140^{\circ} \mathrm{C}\right)$. Firstly, the oxygen atom activated the adsorbed $\mathrm{NH}_{3}$ to form - $\mathrm{NH}$ intermediates, and then the formed -NH interacted with the oxygen atom or gaseous $\mathrm{O}_{2}$ to produce $\mathrm{NO}_{x}$ ad-species under this condition. However, at low temperatures $\left(<140^{\circ} \mathrm{C}\right)$, the adsorbed $\mathrm{NH}_{3}$ mainly interacts with oxygen atom. This may explain the different reaction mechanisms of $\mathrm{NH}_{3}$ oxidation over $\mathrm{H}_{2}-$ pretreated $\mathrm{Ag} / \mathrm{Al}_{2} \mathrm{O}_{3}$ at low temperatures $\left(<140{ }^{\circ} \mathrm{C}\right)$ and at temperatures above $140{ }^{\circ} \mathrm{C}$.

It could be noted that at temperatures above $350{ }^{\circ} \mathrm{C}$ (Fig. 1) a significant amount of $\mathrm{NO}$ desorbed/formed over the $\mathrm{Ag} / \mathrm{Al}_{2} \mathrm{O}_{3}$, primarily because at higher temperatures $\left(>350^{\circ} \mathrm{C}\right)$, the in situformed $\mathrm{NO}_{x}$ could directly desorb as one of the products.

$\mathrm{Ag}^{0}$ has been proposed as the main active species on the $\mathrm{Ag} /$ $\mathrm{Al}_{2} \mathrm{O}_{3}$ in the oxidation of $\mathrm{NH}_{3}$ at low temperatures $\left(<140{ }^{\circ} \mathrm{C}\right)$, while $\mathrm{Ag}^{+}$could also be the active species at temperatures above $140{ }^{\circ} \mathrm{C}$ [17]. In this study, we found that both adsorbed $\mathrm{NH}_{3}$ and $\mathrm{O}_{2}$ could be activated by $\mathrm{Ag}^{0}$, which explains the enhanced low temperature activity. However, the role of $\mathrm{Ag}^{+}$on the $\mathrm{Ag} / \mathrm{Al}_{2} \mathrm{O}_{3}$ in $\mathrm{NH}_{3}$ oxidation is only to activate the adsorbed $\mathrm{NH}_{3}$.

\section{Conclusions}

Chemisorbed oxygen atom enhances the low temperature $\left(<140{ }^{\circ} \mathrm{C}\right)$ activity of $\mathrm{NH}_{3}$ oxidation over $\mathrm{Ag} / \mathrm{Al}_{2} \mathrm{O}_{3}$; in contrast, gas phase $\mathrm{O}_{2}$ mainly interacts with adsorbed $\mathrm{NH}_{3}$ at temperatures above $140{ }^{\circ} \mathrm{C}$. The pathway of $\mathrm{NH}_{3}$ oxidation over $\mathrm{Ag} / \mathrm{Al}_{2} \mathrm{O}_{3}$ at low temperatures $\left(<140^{\circ} \mathrm{C}\right)$ differs from that at temperatures above $140^{\circ} \mathrm{C}$. At low temperatures $\left(<140^{\circ} \mathrm{C}\right), \mathrm{NH}_{3}$ oxidation follows the $-\mathrm{NH}$ mechanism. That is, the adsorbed $\mathrm{NH}_{3}$ first reacts with oxygen atom to form a $-\mathrm{NH}$ intermediate. Then the $-\mathrm{NH}$ interacts with the chemisorbed oxygen atom to form a -HNO intermediate. The interaction of $-\mathrm{NH}$ and $-\mathrm{HNO}$ would produce $\mathrm{N}_{2}$ and $\mathrm{H}_{2} \mathrm{O}$ directly, while two - $\mathrm{HNO}$ would interact to form a $\mathrm{N}_{2} \mathrm{O}$ by- product. At temperatures above $140{ }^{\circ} \mathrm{C}$, the $\mathrm{SCO}$ of $\mathrm{NH}_{3}$ follows an iSCR mechanism. That is, the - $\mathrm{NH}$ mainly reacts with molecular $\mathrm{O}_{2}$ to form NO. Then, the in situ-formed NO interacts with the $\mathrm{NH}_{x}$ and is reduced to $\mathrm{N}_{2}$, with $\mathrm{N}_{2} \mathrm{O}$ as a by-product.

\section{Acknowledgments}

This work was financially supported by the Chinese Academy of Sciences (KZCX1-YW-06-04) and the National Natural Science Foundation of China (10735090).

\section{Appendix A. Supplementary material}

Supplementary data associated with this article can be found, in the online version, at doi:10.1016/j.jcat.2009.08.011.

\section{References}

[1] J. Zawadzki, Disc. Faraday Soc. 8 (1950) 140.

[2] N.I. Il'chenko, G.I. Golodets, J. Catal. 39 (1975) 7.

[3] N.I. Il'chenko, G.I. Golodets, J. Catal. 39 (1975) 73

[4] N.I. Il'chenko, Russ. Chem. Rev. 45 (1976) 1119.

[5] J.M. Bradley, A. Hopkinson, D.A. King, J. Phys. Chem. 99 (1995) 7032

[6] M. Amblard, R. Burch, B.W.L. Southward, Catal. Today 59 (2000) 365.

[7] L.I. Darvell, K. Heiskanen, J.M. Jones, A.B. Ross, P. Simell, A. Williams, Catal. Today 81 (2003) 681.

[8] J.M.G. Amores, V.S. Escribano, G. Ramis, G. Busca, Appl. Catal. B 13 (1997) 45.

[9] L. Chmielarz, P. Kuśtrowski, A. Rafalska-Łasocha, R. Dziembaj, Appl. Catal. B 58 (2005) 235.

[10] G. Qi, J.E. Gatt, R.T. Yang, J. Catal. 226 (2004) 120.

[11] L. Gang, B.G. Anderson, J. van Grondelle, R.A. van Santen, Appl. Catal. B 40 (2003) 101.

[12] G. Qi, R.T. Yang, Appl. Catal. A 287 (2005) 25

[13] L. Gang, B.G. Anderson, J. van Grondelle, R.A. van Santen, J. Catal. 199 (2001) 107.

[14] G. Ramis, L. Yi, G. Busca, M. Turco, E. Kotur, R.J. Willey, J. Catal. 157 (1995) 523.

[15] J.L. Gland, V.N. Korchak, J. Catal. 53 (1978) 97.

[16] V.A. Kondratenko, M. Baerns, Catal. Today 121 (2007) 210

[17] L. Zhang, C. Zhang, H. He, J. Catal. 261 (2009) 101.

[18] L. Lefferts, J.G. van Ommen, J.R.H. Ross, Appl. Catal. 31 (1987) 291

[19] C. Rehren, M. Muhler, X. Bao, R. Schlogl, G. Ertl, Zeitschrift für Physikalische Chemie 174 (1991) 11.

[20] M.A. Larrubia, G. Ramis, G. Busca, Appl. Catal. B 30 (2001) 101.

[21] G. Ramis, M.A. Larrubia, G. Busca, Top. Catal. 11/12 (2000) 161.

[22] W.S. Kijlstra, D.S. Brands, E.K. Poels, A. Bliek, J. Catal. 171 (1997) 208.

[23] H. Zou, J. Shen, Thermochim. Acta 351 (2000) 165.

[24] S.D. Lin, A.C. Gluhoi, B.E. Nieuwenhuys, Catal. Today 90 (2004) 3.

[25] S. He, C. Zhang, M. Yang, Y. Zhang, W. Xu, N. Cao, H. He, Sep. Purif. Technol. 58 (2007) 173.

[26] J. Műslehiddinoğlu, M. Albert Vannice, J. Catal. 217 (2003) 442.

[27] V.A. Matyshak, O.V. Krylov, Catal. Today 25 (1995) 1.

[28] K.I. Hadjiivanov, Catal. Rev. 42 (1\&2) (2000) 71.

[29] X. Wang, H. Chen, W.M.H. Sachtler, J. Catal. 197 (2001) 281

[30] J.E. Germain, R. Perez, Bull. Soc. Chim (France) (1972) 2042.

[31] G.M. Underwood, T.M. Miller, V.H. Grassian, J. Phys. Chem. A 103 (1999) 6184.

[32] H. He, X. Zhang, Q. Wu, C. Zhang, Y. Yu, Catal. Surv. Asia 12 (2008) 38.

[33] X. Zhang, H. He, H. Gao, Y. Yu, Spectrochim. Acta Part A: 71 (2008) 1446.

[34] T. Venkov, K. Hadjiivanov, D. Klissurski, Phys. Chem. Chem. Phys. 4 (2002) 2443.

[35] M. Trombetta, G. Ramis, G. Busca, B. Montanari, A. Vaccari, Langmuir 13 (1997) 4628.

[36] D.P. Sobczyk, E.J.M. Hensen, A.M. de Jong, R.A. van Santen, Top. Catal. 23 (2003) 109.

[37] T. Curtin, F. O’ Regan, C. Deconinck, N. Knüttle, B.K. Hodnett, Catal. Today 55 (2000) 189

[38] G. Ramis, L. Yi, G. Busca, Catal. Today 28 (1996) 373. 